\title{
LONG-TERM TRENDS OF PERSISTENT ORGANOCHLORINE POLLUTANTS, OCCUPANCY, AND REPRODUCTIVE SUCCESS IN PEREGRINE FALCONS (FALCO PEREGRINUS TUNDRIUS) BREEDING NEAR RANKIN INLET, NUNAVUT, CANADA
}

\author{
Alastair Franke ${ }^{1}$, Mike Setterington ${ }^{2 *}$, Gordon Court ${ }^{3}$, And Detlef Birkholz ${ }^{4}$ \\ ${ }^{I}$ Canadian Circumpolar Institute, University of Alberta, 1-42 Pembina Hall, Edmonton, \\ Alberta T6G 2H8, Canada.E-mail: Alastair.Franke@ales.ualberta.ca \\ ${ }^{2}$ Department of Environment, Government of Nunavut, P.O. Box 120, \\ Arviat, Nunavut XOC OEO, Canada \\ *Current address: Environmental Dynamics Incorporated, 3-478 Range Road, \\ Whitehorse, Yukon Y1A 3A2, Canada

\begin{abstract}
${ }^{3}$ Alberta Fish and Wildlife Division, 9920-108 Street, Edmonton, Alberta T5K 2M4, Canada
${ }^{4}$ ALS Laboratory Group, 5424 - 97 Street, Edmonton, Alberta T6E 5C1, Canada
\end{abstract}

\begin{abstract}
The historical decline of the Peregrine Falcon (Falco peregrinus) in North America was attributed mainly to reproductive failure associated with persistent organochlorine pollutants, in particular DDT (dichloro-diphenyl-trichloroethane). It is generally assumed that declining trends in pesticide loads will be accompanied by a corresponding increase in reproduction. In this study, we concurrently measured occupancy, reproductive performance, and pesticide loads of breeding-aged adults on territory near Rankin Inlet, Nunavut, from 1982 to 2009. Our findings indicate that reproductive success of Peregrine Falcons in our study population declined despite concomitant reductions in pesticide loads, and that on average, approximately three fewer territories were occupied annually from 2002 to 2009 than were occupied from 1982 to 1989. In addition, the average number of young to reach banding age annually from 2002 to 2009 was approximately half the number banded annually from 1982 to 1989 . These results indicate that in recent years fewer pairs have attempted to breed; in addition, those that did breed successfully raised fewer young to banding age. In general, the pesticides examined in this study cannot mechanistically explain either the reduction in occupancy or the decline in reproductive performance. We suggest that the proximate effects of local weather patterns - ultimately associated, either directly or indirectly, with overall climate change-have the greatest potential to explain the altered demographic features of the Rankin Inlet population. Reproduced with the permission of the Arctic Institute of North America from Arctic (2010) 63(4):442-450.
\end{abstract}

Franke, A., M. Setterington, G. Court, And D. Birkholz. 2011. Long-term trends of persistent organochlorine pollutants, occupancy and reproductive success in Peregrine Falcons (Falco peregrinus tundrius) breeding near Rankin Inlet, Nunavut, Canada. Reproduced, pages 309-322 in R. T. Watson, T. J. Cade, M. Fuller, G. Hunt, and E. Potapov (Eds.). Gyrfalcons and Ptarmigan in 
a Changing World, Volume II. The Peregrine Fund, Boise, Idaho, USA. http://dx.doi.org/ 10.4080/gpcw.2011.0309

Key words: Peregrine, Falco peregrinus, Arctic, Nunavut, organochlorine, productivity, occupancy, weather, temperature, precipitation, climate change.

Widespread Decline of THE PeRegrine FaLCON (Falco peregrinus) in North America was attributed to reproductive failure (Peakall 1976, Cade et al. 1988) associated with the ubiquitous use of persistent organochlorine pollutants, in particular DDT (dichlorodiphenyl-trichloroethane) (Hickey 1969, Fyfe et al. 1976, Cade et al. 1988, Ratcliffe 1993, Cade and Burnham 2003). Despite bans on the use of DDT imposed in Canada in 1969 and in the United States in 1972 (Kiff 1988), the Peregrine Falcon of continental North America (F. p. anatum) was extirpated over its range east of the Rocky Mountains and south of the boreal forest by 1975 (Fyfe et al. 1976). However, the species has shown considerable recovery over the last two decades (Ambrose et al. 1988, Rowell et al. 2003, Cade and Burnham 2003, Banasch and Holroyd 2004), in part due to the release of captive-bred birds. In 2006, the Committee on the Status of Endangered Wildlife in Canada (COSEWIC) downgraded the threat level for the continental sub-species F. p. anatum from "Threatened" to "Special Concern" (COSEWIC 2006), and the Peregrine Falcon, F. peregrinus, was removed from the United States list of endangered animals in 1999.

The strong recovery of Peregrine Falcon populations in North America is assumed to have been fueled by two main factors: captive breeding with re-introduction and, just as important, a decline in persistent organochlorine residues in Peregrine Falcons and their prey species. Remarkably, there exist relatively few studies of the toxicological status of North American Peregrine populations during this recovery era. Court (1993) assessed the toxicology of Peregrine Falcons (F. p. anatum) breeding in Alberta, Canada between 1968 and
1992, while Court et al. (1990) and Johnstone et al. (1996) reported on the toxicology of the Rankin Inlet population from 1982 to 1986 and 1990 to 1994 , respectively. Jarman et al. (1994) reported on organochlorine compounds in the plasma of Peregrine Falcons nesting in Greenland. More recently, Henny et al. (1996, 2009) reported on trends of organochlorine contaminant levels in migrant Peregrine Falcons captured on Padre Island, Texas, and Vorkamp et al. (2009) summarized long-term trends in residues found in nesting birds in Greenland.

The present study has two primary objectives. The first was to summarize the changes in blood plasma concentration of dichlorodiphenyl-dichloro-ethylene (DDE), a metabolite of DDT; polychlorinated biphenyls (PCBs); and dieldrin in adult Peregrine Falcons captured on territory at Rankin Inlet from 1982 to 2006. The second was to report on annual occupancy and nestling productivity of these birds from 1982 to 2009 . We also present trends in average summer temperature and patterns of precipitation experienced at Rankin Inlet over the same period.

\section{Study Area}

The study population of Peregrine Falcons is encompassed within a $455 \mathrm{~km}^{2}$ study area (Figure 1) near the hamlet of Rankin Inlet, Nunavut, Canada. At peak density, breeding Peregrine Falcons at Rankin Inlet included 29 territorial pairs, or one pair per $15 \mathrm{~km}^{2}$, which is the highest density recorded for the species in the tundra biome and among the highest in the world. Though Rankin Inlet $\left(62^{\circ} 49^{\prime} \mathrm{N}\right.$, $92^{\circ} 05^{\prime} \mathrm{W}$ ) is a relatively southern location for Peregrine Falcons in the Canadian Arctic, 


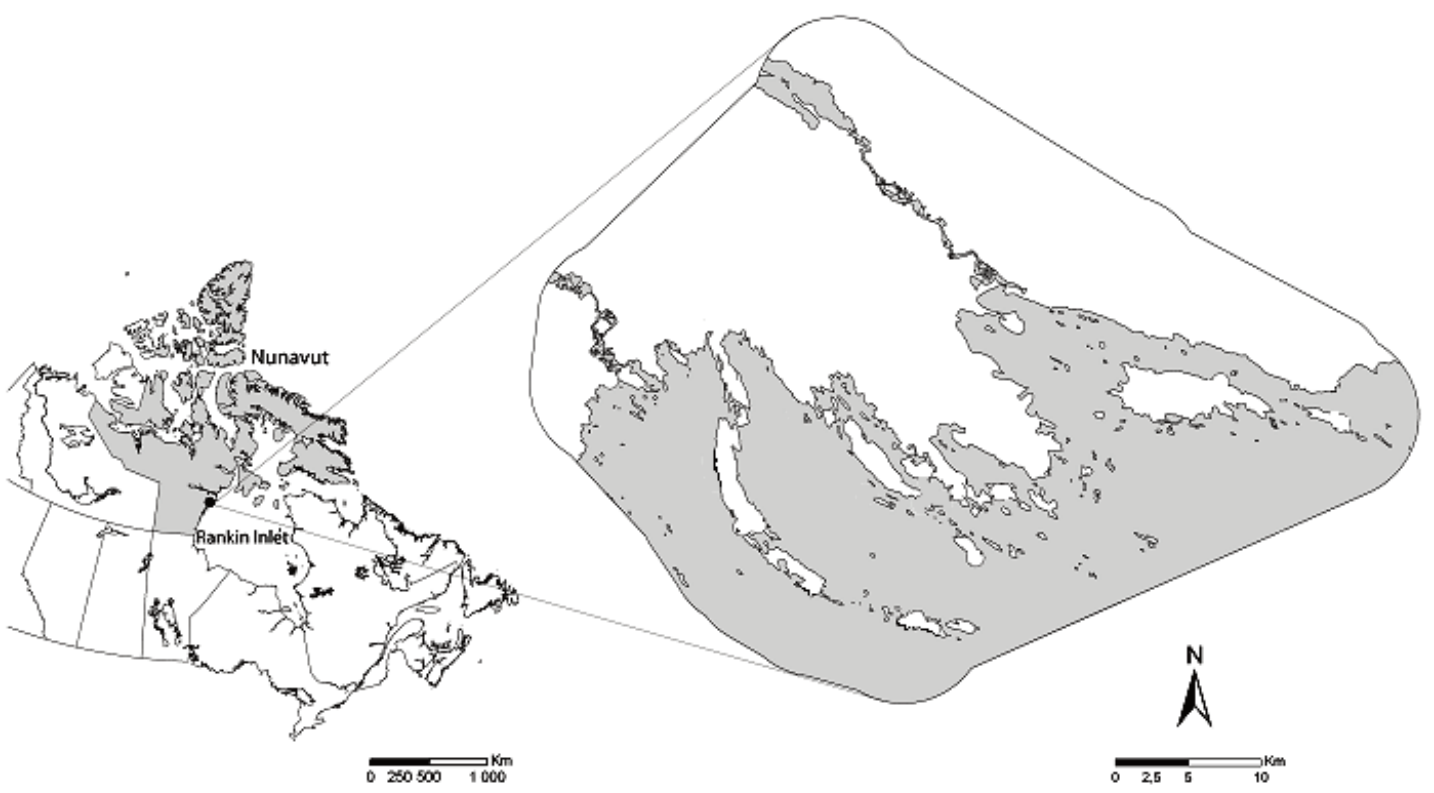

Figure 1. Map of Canada showing the location of the Rankin Inlet, Nunavut, study area (enlarged in inset).

environmental conditions are as severe as, or more severe than, any encountered in the range of the species. Passerines and small mammals comprise the bulk of the diet, and lemming consumption increases significantly during peak abundance (Court et al. 1988a, b, Bradley and Oliphant 1991). Terminology used in describing nesting activities of Peregrine Falcons and a general description of vegetation, climate, and geology of the study area are reported elsewhere (Court 1986, Court et al. 1988a, b, 1989).

\section{MeTHODS}

Occupancy and Reproductive Success.Accurate determination of site occupancy each breeding season was impossible to achieve with a single, short-term survey, particularly if the survey was conducted later in the breeding season (e.g., at a period of time typically associated with brooding or chick rearing). For this reason, from 1982 to 2008, a full census of the entire study area was conducted a minimum of twice annually. Beginning in May of each year, as Peregrine Falcons arrived from their wintering grounds, territories were surveyed by snow machine to determine the presence or absence of territorial, breeding-aged, adults. All unoccupied sites were checked until occupancy by Peregrine Falcons was confirmed, or until the breeding season was sufficiently advanced to conclude that the site was vacant.

In cases where sites were occupied by individuals previously fitted with unique alphanumeric color-coded leg bands, bands were read using a Questar Field Model telescope. If territories were occupied by unmarked individuals, effort was made to trap and mark these birds with an alphanumeric color band on one leg and a US Fish and Wildlife band on the other. In addition, we measured unflattened wing chord, body weight, tail length, and tarsus width and length for each bird and recorded sharpness of keel, a subjective measure of body condition.

After breakup of the sea ice, territories were surveyed by boat to determine occupancy and 
reproduction at each site; inland sites were accessed by all-terrain vehicle for the same purpose. During summer, banded adult Peregrine Falcons were identified either by trapping or visually by telescope. Unmarked individuals were trapped and banded when possible. Once nestlings reached a minimum of 20 days of age (approximately July 25), they too were banded with an alphanumeric color band on one leg and a US Fish and Wildlife band on the other. Only young that survived beyond 20 days and were banded were included in the annual nestling census. Of the 36 known territories distributed throughout the study area, 22 were surveyed annually from 1982 to 2009 . To ensure that data were not biased by inconsistent survey effort, our estimates of site occupancy and productivity were calculated using only the 22 sites surveyed annually in both spring and summer. The years 2000 and 2001 were excluded from this analysis because in 2000 , surveys were conducted only in summer, and in 2001, no survey was conducted at all.

Organochlorine Residues. - We used single factor ANOVA and Tukey post-hoc tests in the statistical package $\mathrm{R}$ to undertake multiple comparisons of means to compare occupancy and total number of young produced, as well as reproductive success across three distinct periods of time (1982-89, 1990-99, and 200209), which allowed us to approximate decadal trends. Productivity (the number of young per territorial pair per year) is an alternative measure of reproductive success that takes into account the number of breeding pairs present on a territory in a given year, regardless of whether the breeding attempt was successful. We therefore calculated productivity in an effort to ensure that changes in the number of young were not related simply to changes in the number of pairs that attempted to breed in any given year.

Between 1982 and 2005, 54 adult male and 93 adult female Peregrine Falcons were captured; approximately $2 \mathrm{ml}$ whole blood was collected from the ulnar vein of each bird using a 23gauge needle and a 3-cc syringe. Some individuals were trapped in multiple years, resulting in a total of 197 blood samples, 61 for males and 136 for females, each of which was considered to be an independent observation. Samples were stored in heparin and centrifuged to separate red cells from plasma. Samples were sealed and stored frozen at $0^{\circ} \mathrm{F}\left(-17^{\circ} \mathrm{C}\right)$ until analysis. All toxicological analyses for samples collected for the periods $1982-1986$ and 1990 - 1996 were conducted at the Health of Animals Laboratory, Food Animal Chemical Residues Section, Agriculture and Agri-Food Canada, in Saskatoon. Preparation of samples, initial assay, and confirmatory gas chromatography-mass spectrometry analyses followed the methods of Won and Turle (1987) and Burse et al. (1983), as used by Court et al. (1990). The quality assurance program run by the Health of Animals Laboratory permitted comparisons between samples collected from 1991 to 1994 (Johnstone et al. 1996) and earlier samples collected by Court et al. (1990). Pesticide reference standards used for quantification were validated according to the Health of Animals Laboratory QA protocol. All remaining samples were analyzed commercially using US Environmental Protection Agency (EPA) Method 8081b (US-EPA 2007a).

Samples were extracted as reported above; however, cleanup of the extracts was performed using a $12 \mathrm{~g}$ Florisil column. The cleanup extract was analyzed using high resolution gas chromatography/electron capture detection. Two columns were used: a $30 \mathrm{~m} \mathrm{x}$ $0.25 \mathrm{~mm}$ I.D. DB-5 and a $30 \mathrm{~m}$ x $0.25 \mathrm{~mm}$ I.D. DB-1701. We used hydrogen carrier gas to illicit maximum peak resolution, and performed dual column confirmation by comparing responses for the two different columns. Analyses for PCBs were performed using Aroclor matching (Method 8082A, US-EPA 2007b). For biological samples, it is generally recognized that this procedure will return higher detection rates than congener-specific analyses (Burse et al. 1990). 


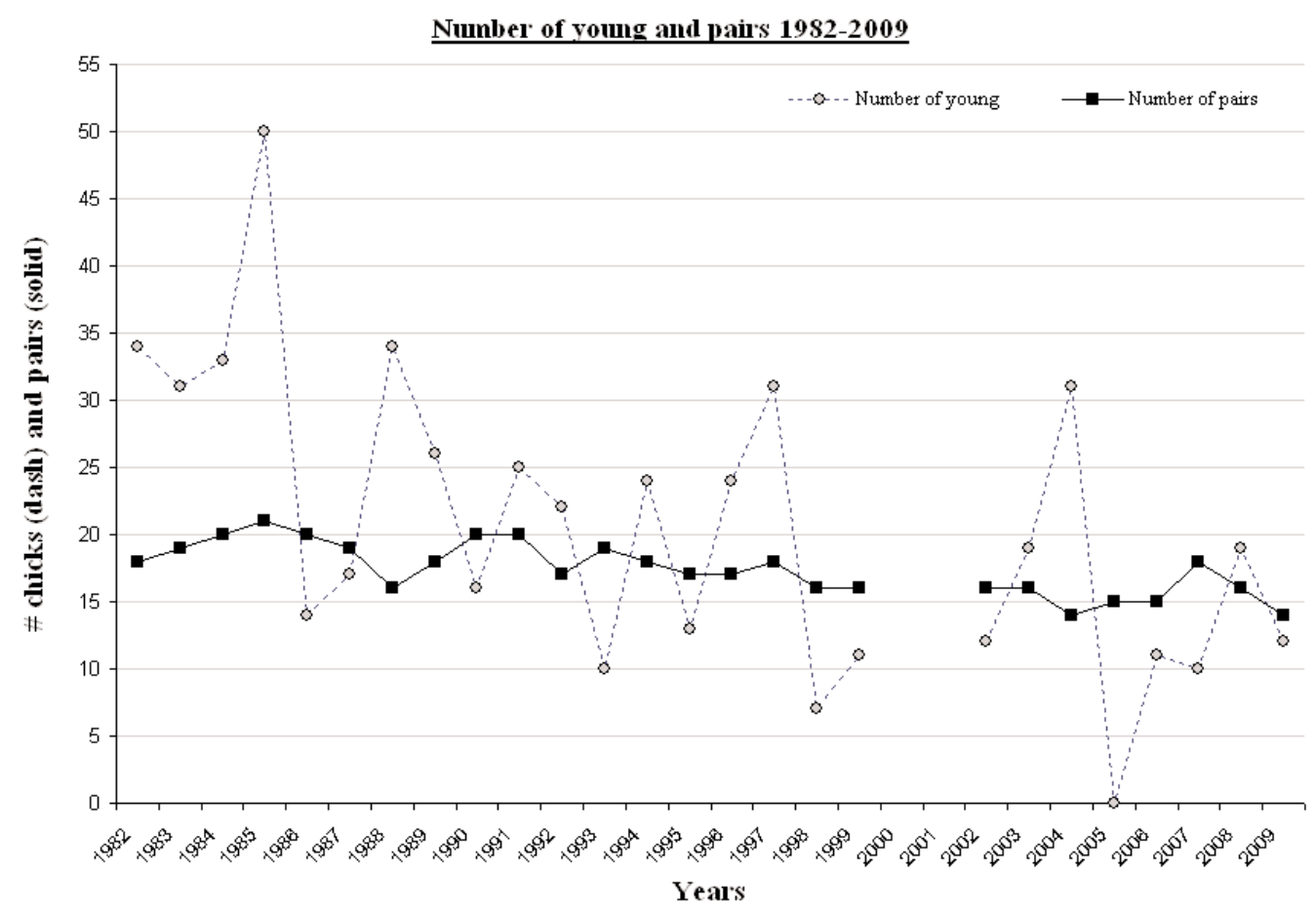

Figure 2. Long-term trends in annual number of territorial pairs and number of young to reach banding age each year for 22 sites in the Rankin Inlet study area monitored from 1982 to 2009.

Data were log-transformed (zero values were set to $0.0005 \mathrm{mg} / \mathrm{kg}$, the stated minimum detection limit) and are reported as geometric mean $\mathrm{mg} / \mathrm{kg}$ wet weight. We used single factor ANOVA and Tukey post-hoc tests in the statistical package $\mathrm{R}$ to undertake multiple comparisons of means to compare blood plasma residues (4,4'-DDE, $\Sigma \mathrm{PCB}$, and dieldrin) across three distinct periods of time (1982-86, 1990-98 and 2004-06).

Weather.-We used Environment Canada weather data collected at the Rankin Inlet airport to calculate average summer temperature $\left({ }^{\circ} \mathrm{C}\right)$, total summer precipitation $(\mathrm{mm})$, and monthly precipitation for June through August for 1982-2009. We used proc AUTOREG in SAS v.9 (SAS Institute 2004) to regress average summer temperature and total precipitation on time, correcting for temporal auto-correlation (and thus dependence) among the residuals (autoregressive error regression). In addition, we calculated the deviation in monthly precipitation from the long-term mean for each month from 1982 to 2009.

\section{RESUlts}

Occupancy and Reproductive Success.-On average, $17.42 \pm 1.96$ of the 22 sites that received consistent survey effort from 1982 to 2009 were occupied annually by a breedingaged pair of Peregrine Falcons and produced an average of $20.27 \pm 11.55$ young annually, resulting in an average of $1.15 \pm 0.62$ nestlings per occupied territory per year (Figure 2, Table $1)$. The range of natural variation across all years was 14-21 for occupancy, 0-50 for total production, and $0.0-2.38$ for productivity (Figure 2, Table 1).

Multiple comparisons of occupancy and total production among time periods indicated a significant decline in both the number of territo- 
Table 1. Summary data (mean \pm SD) for annual occupancy at 22 sites monitored for territorial adults, total production (number of young banded each year), and productivity (number of young per occupied territory) of Peregrine Falcons breeding near Rankin Inlet, Nunavut, from 1982 to 2009.

\begin{tabular}{lccc}
\hline & Occupancy & Production & Productivity \\
\hline Mean + SD & & & $1.15 \pm 0.62$ \\
$1982-2009$ & $17.42 \pm 1.96$ & $20.27 \pm 11.55$ & $1.59 \pm 0.58^{\mathrm{a}}$ \\
$1982-1989$ & $18.88 \pm 1.55^{\mathrm{ab} *}$ & $29.88 \pm 11.23^{\mathrm{a}}$ & $0.97 \pm 0.51^{\mathrm{b}}$ \\
$1990-1999$ & $17.80 \pm 1.48^{\mathrm{abc}}$ & $17.40 \pm 9.26^{\mathrm{b}}$ & $0.94 \pm 0.64^{\mathrm{bc}}$ \\
$2002-2009$ & $15.50 \pm 1.31^{\mathrm{c}}$ & $14.25 \pm 9.00 \mathrm{~b}^{\mathrm{c}}$ & \\
Range & & & $0.7-2.38$ \\
$1982-1989$ & $16-21$ & $14-50$ & $0.8-1.74$ \\
$1990-1999$ & $16-20$ & $2-31$ & $0.0-2.21$ \\
$2002-2009$ & $14-18$ & $0-31$ & \\
\hline
\end{tabular}

* Means in the same column that share a superscript letter are not significantly different.

rial pairs $(\mathrm{P}<0.001)$ and the number of young produced $(\mathrm{P}<0.01)$. There was no difference $(\mathrm{P}=0.28)$ in the number of occupied territories when comparing the $1980 \mathrm{~s}$ (mean $=18.88 \pm$ $1.55)$ and the $1990 \mathrm{~s}$ (mean $=17.80 \pm 1.48)$. However, fewer territories were occupied in the 2000s $($ mean $=15.50 \pm 1.31)$ than in the $1980 \mathrm{~s}($ mean $=18.88 \pm 1.55, \mathrm{P}<0.001)$ and the $1990 \mathrm{~s}($ mean $=17.80 \pm 1.48, \mathrm{P}<0.01)$.

For total production, a comparison among time periods indicates there was no difference $(\mathrm{P}=$ 0.77 ) between the $1990 \mathrm{~s}$ (mean $=17.40 \pm$ 9.26 ) and the $2000 \mathrm{~s}$ (mean $=14.25 \pm 9.00)$. However, a significant decline is evident in comparisons between the 1980s ( mean $=29.88$ \pm 11.23 ) and both the 1990s (mean $=17.40 \pm$ $9.26, \mathrm{P}<0.05$ ) and the 2000s (mean $=14.25 \pm$ $9.00, \mathrm{P}=0.10)$.

Despite our correction for the number of territories occupied each year, the decline in reproductive success as estimated by productivity remained consistent with the decline observed for total production. We found no difference $(\mathrm{P}$ $=0.99)$ between estimates of productivity observed in the 2000s (mean $=0.94 \pm 0.64$ ) and those observed in the 1990s (mean $=0.97$ \pm 0.51 ). Nevertheless, significant declines in productivity were apparent when we compared the $1980 \mathrm{~s}($ mean $=1.59 \pm 0.58)$ to the $1990 \mathrm{~s}$ (mean $=0.97 \pm 0.51, \mathrm{P}<0.10)$ and the $2000 \mathrm{~s}$ $($ mean $=0.94 \pm 0.64, \mathrm{P}<0.10)$.
Organochlorine Residues.-Results for both sexes combined (Table 2) indicate that plasma DDE levels in adult Peregrine Falcons breeding in Rankin Inlet were significantly higher in the $1980 \mathrm{~s}$ (geometric mean $=0.76 \mathrm{mg} / \mathrm{kg}$ ) than in the $1990 \mathrm{~s}(0.27 \mathrm{mg} / \mathrm{kg}, \mathrm{P}<0.001)$ and the $2000 \mathrm{~s}(0.12 \mathrm{mg} / \mathrm{kg}, \mathrm{P}<0.001)$. However, there was no difference in the geometric means for plasma DDE levels recorded in the 1990s and the 2000s $(\mathrm{P}=0.359)$.

For adult males, plasma DDE levels were significantly higher in the 1980s (geometric mean $=0.93 \mathrm{mg} / \mathrm{kg}$ ) than in the $1990 \mathrm{~s}$ (geometric mean $=0.18 \mathrm{mg} / \mathrm{kg}, \mathrm{P}<0.001)$ and the $2000 \mathrm{~s}$ (geometric mean $=0.05 \mathrm{mg} / \mathrm{kg}, \mathrm{P}<0.001)$. However, there was no difference in the geometric means for plasma DDE levels recorded in the 1990s and 2000s $(P=0.334)$. Females also had a significant decline in plasma DDE levels from the 1980s (geometric mean $=0.70$ $\mathrm{mg} / \mathrm{kg}$ ) to the $1990 \mathrm{~s}$ (geometric mean $=0.31$ $\mathrm{mg} / \mathrm{kg}, \mathrm{P}=0.02$ ); however, the declines observed in the 2000s were not statistically significant compared to the $1980 \mathrm{~s}(\mathrm{P}=0.11)$ or the 1990s $(\mathrm{P}=0.95)$.

For both sexes combined, PCB residues declined significantly from the 1980 s $(0.64$ $\mathrm{mg} / \mathrm{kg})$ to the $1990 \mathrm{~s}(0.11 \mathrm{mg} / \mathrm{kg}, \mathrm{P}<0.001$; Table 3), but there was no significant difference between the $1980 \mathrm{~s}(0.64 \mathrm{mg} / \mathrm{kg})$ and the 2000s $(0.32 \mathrm{mg} / \mathrm{kg}, \mathrm{P}=0.39)$, or between the 
Table 2. DDE (geometric mean and maximum levels) in blood plasma of adult Peregrine Falcons captured on territory in Rankin Inlet, Nunavut, 1982 - 2006.

\begin{tabular}{|c|c|c|c|c|c|c|c|c|c|}
\hline \multirow[b]{2}{*}{ Time Period } & \multicolumn{2}{|c|}{ Both Sexes } & & \multicolumn{2}{|c|}{ Females } & & \multicolumn{2}{|c|}{ Males } & \\
\hline & 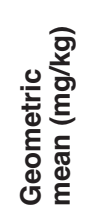 & 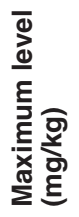 & $z$ & 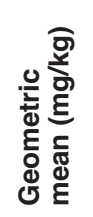 & 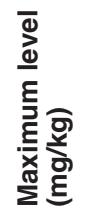 & $z$ & 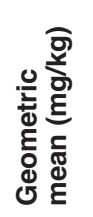 & 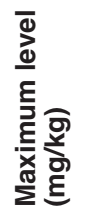 & $z$ \\
\hline $1982-86$ & $0.76^{a^{\star}}$ & 8.19 & 75 & $0.70^{a}$ & 6.56 & 55 & $0.93^{a}$ & 8.19 & 20 \\
\hline 1990-98 & $0.27^{b}$ & 4.45 & 97 & $0.31^{\mathrm{b}}$ & 4.45 & 66 & $0.18^{b}$ & 1.95 & 31 \\
\hline 2004-06 & $0.12^{\mathrm{bc}}$ & 5.40 & 25 & $0.23^{a b}$ & 5.40 & 16 & $0.05^{\mathrm{bc}}$ & 0.33 & 9 \\
\hline
\end{tabular}

* Means in the same column that share a superscript letter are not significantly different.

Table 3. $\Sigma$ PCB (geometric mean and maximum levels) in blood plasma of adult Peregrine Falcons captured on territory in Rankin Inlet, Nunavut, 1982-2006.

\begin{tabular}{|c|c|c|c|c|c|c|c|c|c|}
\hline \multirow[b]{2}{*}{ Time Period } & \multicolumn{2}{|c|}{ Both Sexes } & & \multicolumn{2}{|c|}{ Females } & \multirow[b]{2}{*}{$z$} & \multicolumn{2}{|c|}{ Males } & \multirow[b]{2}{*}{$\mathbf{z}$} \\
\hline & 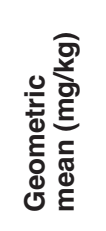 & 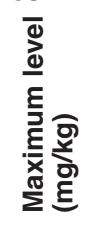 & $\mathbf{z}$ & 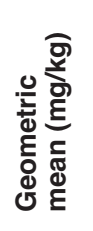 & 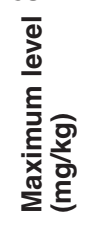 & & 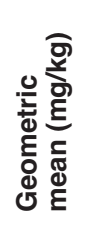 & 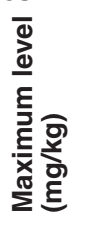 & \\
\hline $1982-86$ & $0.64^{a^{\star}}$ & 3.84 & 70 & $0.66^{a}$ & 3.84 & 53 & $0.58^{\mathrm{a}}$ & 2.55 & 17 \\
\hline 1990-98 & $0.11^{\mathrm{b}}$ & 13.86 & 97 & $0.40^{\mathrm{a}}$ & 13.86 & 66 & $0.01^{b}$ & 3.27 & 31 \\
\hline 2004-06 & $0.32^{\mathrm{a}}$ & 3.50 & 25 & $0.57^{a}$ & 2.40 & 16 & $0.11^{\mathrm{ca}}$ & 2.80 & 9 \\
\hline
\end{tabular}

${ }^{*}$ Means in the same column that share a superscript letter are not significantly different.

Table 4. Dieldrin (geometric mean and maximum levels) in blood plasma of adult Peregrine Falcons captured on territory in Rankin Inlet, Nunavut, 1982-2006.

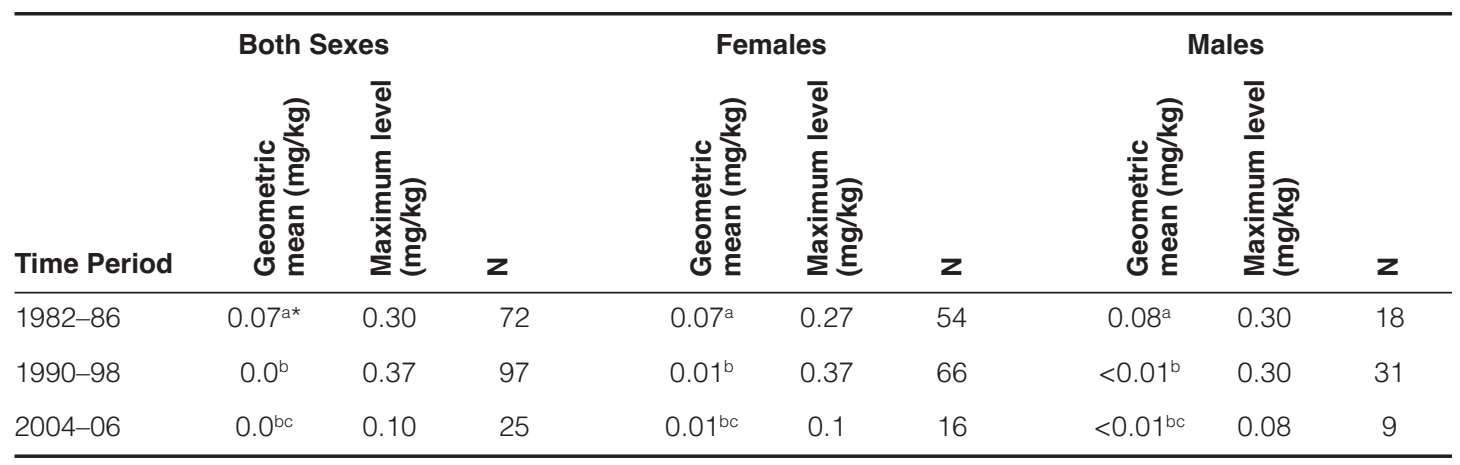

${ }^{*}$ Means in the same column that share a superscript letter are not significantly different. 
$1990 \mathrm{~s}(0.11 \mathrm{mg} / \mathrm{kg})$ and the $2000 \mathrm{~s}(0.32$ $\mathrm{mg} / \mathrm{kg}, \mathrm{P}=0.15)$. Taking sex into account, we found that although both sexes experienced reduced $\Sigma$ PCB burden between the 1980s and 1990 s, only males experienced a significant reduction (from $0.58 \mathrm{mg} / \mathrm{kg}$ to $0.01 \mathrm{mg} / \mathrm{kg}, \mathrm{P}$ $<0.001$ ), while that in females was not statistically significant (from $0.66 \mathrm{mg} / \mathrm{kg}$ to 0.40 $\mathrm{mg} / \mathrm{kg}, \mathrm{P}=0.24)$. Whether considered together or separately, male and female Peregrine Falcons captured on territory at Rankin Inlet in the 2000s showed higher levels of PCBs (males: $0.11 \mathrm{mg} / \mathrm{kg}$; females: $0.57 \mathrm{mg} / \mathrm{kg}$ ) than the cohort captured during the 1990s (males: 0.01 $\mathrm{mg} / \mathrm{kg}$; females: $0.40 \mathrm{mg} / \mathrm{kg}$ ).

Appreciable levels of dieldrin were recorded in samples of blood plasma collected from adults of both sexes from 1982 to 1986 (Table 4). The geometric means recorded during this period were $0.07 \mathrm{mg} / \mathrm{kg}$ for females and $0.08 \mathrm{mg} / \mathrm{kg}$ for males, and maximum levels were $0.27 \mathrm{mg} / \mathrm{kg}$ for females and $0.30 \mathrm{mg} / \mathrm{kg}$ for males. Although maximum levels recorded in the population in the 1990s remained the same or increased regardless of sex, the geometric means for both sexes declined significantly from those recorded from 1982 to 1986 (Table 4).

The geometric means for both sexes decreased no further in the 2000s from values recorded in the previous time period (1990-98); however, substantial declines were evident in the maximum values recorded in the population. Over the course of the study, maximum dieldrin levels decreased to about one-third of their previous levels in both females (from $0.27 \mathrm{mg} / \mathrm{kg}$ in the $1980 \mathrm{~s}$ to $0.10 \mathrm{mg} / \mathrm{kg}$ in the $2000 \mathrm{~s}$ ), and males (from $0.30 \mathrm{mg} / \mathrm{kg}$ to $0.08 \mathrm{mg} / \mathrm{kg}$ ).

Weather.-The average summer temperature measured at Rankin Inlet increased by approximately $1.5^{\circ} \mathrm{C}$ (slope: $0.065 \pm 0.02 \mathrm{SE}, \mathrm{P}=$ $0.008 ; R^{2}=0.23$ ) from 1982 to 2009 (Figure 3 ). Although we found a declining trend (slope $=-1.30$ ) in total precipitation for the same period, it was not significantly different from zero $(P=0.19)$. Similarly, deviations calcu-

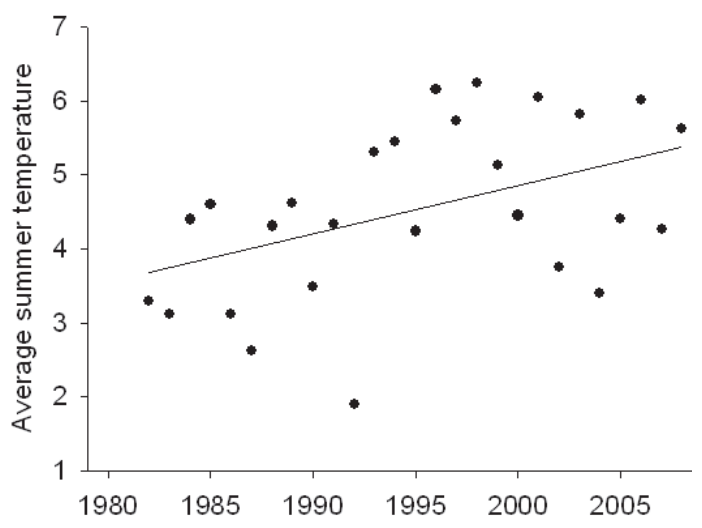

Figure 3. Average summer temperature (average monthly temperature from June to August, ${ }^{\circ} \mathrm{C}$ ) at Rankin Inlet, Nunavut, Canada from 1982 to 2008. Line represents the estimated linear trend (slope: $0.065 \pm 0.02 \mathrm{SE}, \mathrm{p}=0.008$, $\left.R^{2}=0.23\right)$. The regression was performed with proc AUTOREG in SAS v.9 (SAS Institute 2004), correcting for temporal auto-correlation, and thus dependence, among the residuals (autoregressive error regression).

lated for each month from the averages calculated for June (slope $=-0.81$ ), July (slope $=$ 0.33), and August (-0.34) from 1982 to 2009 were not significantly different from zero.

\section{DisCUSSION}

Pollutant status and reproductive dysfunction in Peregrine Falcons are well documented both for populations in North America in general (Berger et al. 1970; Peakall and Kiff 1988; Peakall et al. 1990) and in the Rankin Inlet study area specifically (Court et al. 1990; Johnstone et al. 1996). Of the contaminants measured here, only DDE is known to have been associated with population declines (from eggshell thinning) in North American Peregrine Falcon populations, and although the effects of dieldrin were reportedly absent in North American Peregrine Falcons (Risebrough and Peakall 1988), this contaminant was considered important in the British Isles (Nisbet 1988). The effects of PCBs on Peregrines, if any, remain unknown, but at least it 
is well established that neither PCBs nor dieldrin contributes to eggshell thinning.

Although this analysis showed that some individuals within the Rankin Inlet population were as contaminated in recent years as their ancestors were more than 25 years ago, overall population-level organochlorine residues in Peregrine Falcons have shown a significant decline over the last three decades. Furthermore, levels recorded throughout the study period, and in particular those recorded more recently, are significantly below levels (1.8$2.4 \mathrm{ppm}$ in serum) known to cause problems in eggshells (Peakall and Kiff 1988; Court et al. 1990). We believe that Peregrine Falcons that breed near Rankin Inlet no longer face a direct threat from the pollutants investigated in this study, and in this regard, there is good reason to be optimistic about the future of Peregrine Falcons breeding at Rankin Inlet. Similar trends have been noted previously by other authors (Jarman et al. 1994; Henny et al. 1996, 2009; Ambrose et al. 2000; Clark et al. 2009) investigating pollutant levels in Peregrine Falcons in other jurisdictions, and we suggest that this trend most likely applies to other Canadian populations.

It is generally assumed that declining trends in pesticide loads will be accompanied by a corresponding increase in productivity. We therefore measured occupancy, reproductive performance, and pesticide loads concurrently. However, our findings indicated that reproductive success of Peregrine Falcons in our study population declined despite concomitant reductions in pesticide loads. On average, approximately three fewer territories were occupied annually from 2002 to 2009 than were occupied from 1982 to 1989 . The overall decline in reproductive success can likely be explained in part by the presence of fewer pairs attempting to breed each year. However, it is important to note that productivity, which accounts for the number of occupied territories, also declined significantly. Considered together, these results indicate that in recent years fewer pairs have attempted to breed, and in addition, those that were successful in breeding raised fewer young to banding age ( $\geq$ 20 days of age). In general, the pesticides examined in this study cannot mechanistically explain either the reduction in occupancy or the decline in reproductive performance.

Although the mechanism or mechanisms (e.g., disease, predation) associated with the reported declines are unclear, the proximate effects of local weather patterns - ultimately associated, either directly or indirectly, with overall climate change - may be noteworthy in regard to explaining the altered demographic features evident in the Rankin Inlet population. We suggest that this factor is particularly important given the documented rise in average summer temperature recorded in Rankin Inlet over the course of this study. Although the patterns in precipitation examined here indicate that there was no significant change in either the amount of rain and snow or the manner in which total precipitation was distributed through the summer months from 1982 to 2009, it is interesting to note that the slope calculated for average summer precipitation was negative, as were slopes for the deviations in June and August precipitation each year relative to mean June and August precipitation for all years of the study. Conversely, a positive slope was calculated for the deviation in July precipitation each year relative to mean July precipitation for all years of the study. It is thus feasible that in recent years both June and August may have become drier, while July may have become wetter. Increased precipitation in the month of July, even if associated with reduced precipitation in June and August, could easily result in widespread loss of broods, as nestlings typically hatch around July 11 and remain particularly vulnerable to the direct effects of cold and wet conditions until at least 21 days of age. Recently, motion-sensitive cameras deployed in our study area have documented several cases of nest flooding (e.g., Figure 4) and have shown that otherwise healthy broods of young can perish in as few as two hours after direct 


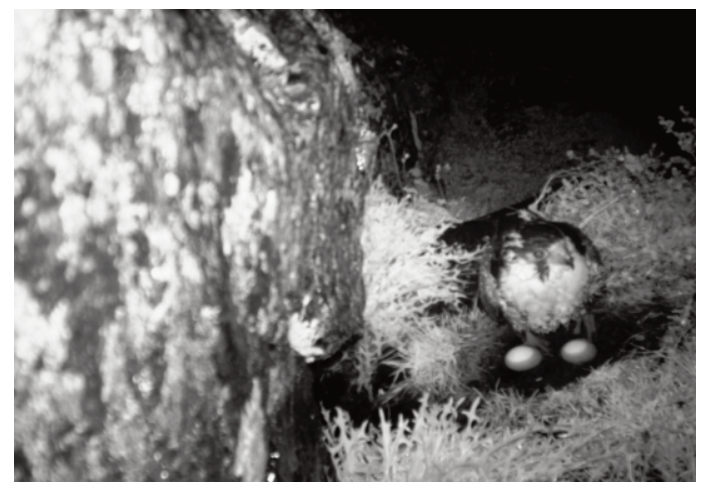

Figure 4. A soaked adult female Peregrine Falcon breeding near Rankin Inlet, Nunavut, stands beside a clutch of almost entirely submerged eggs.

exposure to cold, wet conditions. In these cases, photographic evidence indicated that weather-killed young were either fed to siblings or consumed or cached by the parents. In other cases where cameras were not present, but the presence of healthy nestlings had been confirmed immediately prior to an extended period of inclement weather, it was not unusual for follow-up monitoring of the same sites soon after the poor-weather period to document a reduction in brood size or a total absence of nestlings. At sites where collection of dead young was possible immediately after extended periods of rainfall, young were often found huddled together, and on occasion, examination of the carcasses revealed that nestlings had died prior to passage of food from the crop into the proventriculus (i.e., they had not starved).

Alternatively, poor weather may indirectly influence annual reproductive success of Peregrine Falcons in a "bottom-up" manner via availability of food resources. Repeated site visits revealed that in some cases, nestlings that had been initially spared from the direct effects of poor weather (by either parental care or advanced feather growth) later died as a result of poor body condition. In these instances, we believe that the abundance of prey species (primarily juvenile ground-nesting passerines) was reduced by adverse weather conditions to levels at which adult Peregrine Falcons were not able to provision young adequately. In recent years, the carcasses of several nestlings that showed poor rates of growth or sudden declines in body weight at some point during rearing were collected, and post-mortem examination clearly indicated that these young had been severely food-limited prior to their deaths. In several cases, all nestlings within a brood experienced significant weight loss (50-160 g each) during periods when the feeding rate decreased from 6-7 prey items per day to $1-2$ per day. Brood size was routinely reduced in these cases.

The results reported here emphasize how important it is for wildlife agencies to continue monitoring reproductive success of Peregrine Falcons and encourage routine residue scans in their tissues to detect any sharp changes in either hatching success or chemical residues over time. In addition, declining levels of organochlorine residues found in Peregrine tissue leave little room for complacency. Although there are global initiatives in place to eliminate the manufacture and use of many of the most environmentally damaging compounds, strong lobbies exist that aim to resurrect chemicals like DDT as a short-term measure to control malaria and other insectborne diseases in developing nations (Raloff 2000). As virtually all the Peregrine Falcons from northern Canada overwinter in Mexico, Central America, and South America, any move to resume DDT use on a large scale will be detrimental to these birds.

Finally, it is important to note that our comments with regard to the observed downward trends in occupancy and reproductive success are limited to Peregrine Falcons breeding at Rankin Inlet. Such trends may exist at broader scales, but larger patterns can be clarified only by incorporating additional, geographically distinct areas into the study. 


\section{ACKNOWLEDGMENTS}

This research was funded by ArcticNet, the Nunavut Wildlife Management Board, and the Department of Environment, Government of Nunavut. We thank Andy Aliyak, Poisey Alogut, Vincent L'Herault, Alex Anctil, and Hilde Johansen for their contributions to fieldwork, and Mark Bradley, Tom Duncan, Robin Johnstone, and Dave Abernethy, who contributed data used in the analysis. Vincent L'Herault produced the map of the study area. Jean-Francois Therrien provided precipitation summaries, and Sebastien Descamps provided the temperature summary. We are extremely grateful for the help and support that we received from personnel of the Department of Environment, especially Mitch Campbell, Raymond Mercer, David Oolooyuk, Darren Conroy, Johanne Coutu-Autut, and Peter Kattegatsiak. We thank the members of the Kangiqliniq Hunters and Trappers Organization for their approval and ongoing support for this research. We are also very grateful to Mike Shouldice and Dorothy Tootoo from the Nunavut Arctic College and to the people of Rankin Inlet. We also wish to acknowledge the contribution of three anonymous reviewers, whose comments resulted in a much-improved manuscript.

\section{Literature Cited}

Ambrose, R. E., R. J. Ritchie, C. M. White, P. F. SCHEMPF, T. SWEM, AND R. DitTRICK. 1988. Changes in the status of the Peregrine Falcon populations in Alaska. Pages 73-82 in T. J. Cade, J. H. Enderson, C. G. Thelander, and C. M. White (Eds.). Peregrine Falcon Populations: Their Management and Recovery. The Peregrine Fund, Boise, Idaho, USA.

Ambrose, R. E., A. Matz, T. Swem, And P. BENTE. 2000. Environmental contaminants in American and Arctic Peregrine Falcon eggs in Alaska, 1979-95. US Fish and Wildlife Service, Northern Alaska Ecological Services, Fairbanks, Alaska, USA.
Banasch, U., And G. Holroyd. 2004. The 1995 Peregrine Falcon survey in Canada. Occasional Paper no. 110. Canadian Wildlife Service, Environment Canada. Ottawa, Canada.

Bradley, M., AND L. W. Oliphant. 1991. The diet of Peregrine Falcons in Rankin Inlet, Northwest Territories: An unusually high proportion of mammalian prey. Condor 93:193-197.

Berger, D. D., D. W. Anderson, J. D. WeAVER, AND R. W. Risebrough. 1970. Shell thinning in eggs of Ungava Peregrines. Canadian Field-Naturalist 84:265267.

Burse, V. W., L. L. Needham, M. P. Korver, C. R. LAPZERA, JR., AND D. D. BAYSE. 1983. Gas-liquid chromatographic determination of polychlorinated biphenyls and a selected number of chlorinated hydrocarbons in serum. Journal of the Association of Official Analytical Chemists 66:32-39.

Burse, V. W., D. F. Groce, M. P. Korver, P. C. McClure, S. L. Head, L. L. Needham, C. R. LAPEZA, JR., AND A. L. SMREK. 1990. Use of reference pools to compare the qualitative and quantitative determination of polychlorinated biphenyls by packed and capillary gas chromatography with electron capture detection. Part 1. Serum. Analyst 115:243-251.

CADE, T. J., AND W. BuRnham. 2003. Return of the Peregrine: A North American Saga of Teamwork and Tenacity. The Peregrine Fund, Boise, Idaho, USA.

CAde, T. J., J. H. Enderson, C. G. Thelander, AND C. M. WhITE. 1988. Peregrine Falcon Populations: Their Management and Recovery. The Peregrine Fund, Boise, Idaho, USA.

Clark, K. E., Y. Zhao, and C. M. Kane. 2009. Organochlorine pesticides, PCBs, dioxins, and metals in postterm Peregrine Falcon (Falco peregrinus) eggs from the Mid-Atlantic states, 1993-1999. Archives of Environmental Contamination and Toxicology 57:174-184. 
COSEWIC (Committee on the Status of ENDANGERED WILDLIFE IN CANADA). 2006. Canadian Species at Risk.

CourT, G. S. 1986. Some aspects of the reproductive biology of Tundra Peregrine Falcons. M.Sc. thesis, University of Alberta, Edmonton, Alberta, Canada.

CourT, G. S. 1993. A toxicological assessment of the American Peregrine Falcon (Falco peregrinus anatum) breeding in Alberta, Canada, 1968 to 1992. Occasional Paper no. 10. Department of Environmental Protection, Fish and Wildlife Division, Government of Alberta, Edmonton, Canada.

Court, G. S., C. C. Gates, And D. A. Boag. 1988a. Natural history of the Peregrine Falcon in the Keewatin District of the Northwest Territories. Arctic 41:17-30.

Court, G. S., D. M. Bradley, C. C. Gates, AND D. A. BoAg. 1988b. The population biology of Peregrine Falcons in the Keewatin District of the Northwest Territories, Canada. Pages 729-739 in T. J. Cade, J. H. Enderson, C. G. Thelander, and C. M. White, (Eds.). Peregrine Falcon Populations: Their Management and Recovery. The Peregrine Fund, Boise, Idaho, USA.

Court, G. S., D. M. Bradley, C. C. Gates, AND D. A. BoAg. 1989. Turnover and recruitment in a tundra population of Peregrine Falcons Falco peregrinus. Ibis 131:487-496. http://dx.doi.org/10.1111/ j.1474-919X.1989.tb04785.x

Court, G. S., C. C. Gates, D. A. Boag, J. D. MacNeil, D. M. Bradley, A. C. Fesser, J. R. Patterson, G. B. Stenhouse, and L. W. OLIPHANT. 1990. A toxicological assessment of Peregrine Falcons, Falco peregrinus tundrius, breeding in the Keewatin District of the Northwest Territories, Canada. Canadian Field-Naturalist 104:255-272.

Fyfe, R.W., S. A. Temple, and T. J.Cade. 1976. The 1975 North American Peregrine survey. Canadian Field-Naturalist 90:228273.

Henny, C. J., W. S. SeEgar, AND T. L. MaechTLE. 1996. DDE decreases in plasma of spring migrant Peregrine Falcons, 197894. Journal of Wildlife Management 60:342-349.

Henny, C. J., M. A. Yates, and W. S, Seegar. 2009. Dramatic declines of DDE and other organochlorines in spring migrant Peregrine Falcons from Padre Island, Texas, 1978-2004. Journal of Raptor Research 43:37-42.

Hickey, J. J. 1969. Peregrine Falcon Populations: Their Biology and Decline. University of Wisconsin Press, Madison, Wisconsin, USA.

Jarman, W. M., S. A. Burns, W. G. Mattox, AND W. S. SeEgAR. 1994. Organochlorine compounds in the plasma of Peregrine Falcons and Gyrfalcons nesting in Greenland. Arctic 47:334-340.

Johnstone, R. M., G. S. Court, A. C. Fesser, D. M. Bradley, L. W. Oliphant, AND J. D. MACNEIL. 1996. Long-term trends and sources of organochlorine contamination in Canadian tundra Peregrine Falcons, Falco peregrinus tundrius. Environmental Pollution 93:109-120. http://dx.doi.org/10.1016/ 0269-7491(96)00037-1

KIFF, L. F. 1988. Changes in the status of the Peregrine in North America: An overview. Pages 123-129 in T. J. Cade, J. H. Enderson, C. G. Thelander, and C. M. White (Eds.). Peregrine Falcon Populations: Their Management and Recovery. The Peregrine Fund, Boise, Idaho, USA.

Nisbet, I. C. T. 1988. The relative importance of DDE and dieldrin in the decline of Peregrine Falcon populations. Pages 351-375 in T. J. Cade, J. H. Enderson, C. G. Thelander, and C. M. White (Eds.). Peregrine Falcon Populations: Their Management and Recovery. The Peregrine Fund, Boise, Idaho, USA.

Peakall, D. B. 1976. The Peregrine Falcon (Falco peregrinus) and pesticides. Canadian Field-Naturalist 90:301-307.

Peakall, D. B., And L. F. KIFF. 1988. DDE contamination in Peregrines and American Kestrels and its effect on reproduction. Pages 337-350 in T. J. Cade, J. H. Ender- 
son, C. G. Thelander, and C. M. White (Eds.). Peregrine Falcon Populations: Their Management and Recovery. The Peregrine Fund, Boise, Idaho, USA.

Peakall, D. B., D. G. Noble, J. E. Elliot, J. D. SOMERS, AND G. ERICKSON. 1990. Environmental contaminants in Canadian Peregrine Falcons, Falco peregrinus: A toxicological assessment. Canadian FieldNaturalist 104:244-254.

RALOFF, J. 2000. The case for DDT: What do you do when a dreaded environmental pollutant saves lives? Science News 158:1214.

Ratcliffe, D. 1993. The Peregrine Falcon. T. \& A. D. Poyser, London, UK.

Risebrough, R. W., AND D. B. Peakall. 1988. The relative importance of the several organochlorines in the decline of Peregrine Falcon populations. Pages 449-462 in T. J. Cade, J. H. Enderson, C. G. Thelander, and C. M. White (Eds.). Peregrine Falcon Populations: Their Management and Recovery. The Peregrine Fund, Boise, Idaho, USA. Rowell, P., G. L. Holroyd, AND U. Banasch. 2003. The 2000 Canadian Peregrine Falcon survey. Journal of Raptor Research 37:98116.
SAS Institute. 2004. SAS/STAT 9.1 User's Guide. SAS Publishing, Cary, North Carolina, USA.

US EPA (United STATES ENVIRONMENTAL PROTECTION AGENCY). 2007a. Method 8081B: Organochloride pesticides by gas chromatography.

http://www.epa.gov/waste/hazard/testmethods/sw846/pdfs/8081b.pdf

US EPA (UNITED STATES ENVIRONMENTAL PROTECTION AGENCY). 2007b. Method 8082A: Polychlorinated biphenyls (PCBs) by gas chromatography. http://www.epa.gov/waste/hazard/testmethods/sw846/pdfs/8082a.pdf

Vorkamp, K., M. Thomsen, S. Møller, K. FALK, AND P. B. SøRENSON. 2009. Persistent organochlorine compounds in Peregrine Falcon (Falco peregrinus) eggs from South Greenland: Levels and temporal changes between 1986 and 2003. Environment International 35:336-341. doi:10.1016/ j.envint 2008.08 .008

Won, H., AND R. TuRLE. 1987. Methods of analysis. Canadian Wildlife Service Report Series 87-00. Canadian Wildlife Service, National Wildlife Research Centre, Ottawa, Canada. 
- Franke et Al. - 